\title{
Education and Reminder Software for Strength- ening Anemia Prevention Program in Adolescent Girls
}

\author{
Dian Rohmatika ${ }^{1}$, Bedjo Santoso $^{2}$, Leny Latifah ${ }^{3}$, Melyana Nurul Widyawati ${ }^{4}$ \\ \{dianrohmatika@ymail.com ${ }^{1}$, bedjosantoso27@gmail.com ${ }^{2}$, lenylatifah1@gmail.com ${ }^{3}$ \} \\ Poltekkes Kemenkes Semarang, Semarang, Indonesia ${ }^{1,2,3,4}$
}

\begin{abstract}
Adolescent girls, an important period for ensuring reproductive health, are tend to had anemia. Good Nutrition and consuming iron supplementation once a week which is a government program, proven effective to prevent anemia. But, the lack of knowledge and adherence of adolescent girls to consume iron supplementation hinders the success of the program. Smartphone-based education media is a compelling alternative. The study aimed to develop a smartphone-based intervention model to educate adolescent girls about anaemia and facilitating adherence of iron supplementation consumption. This was an R and D (Research and Development) study, using the 6 steps System Development Life Cycle, namely: 1. Planning. 2. Analysis, 3. Design, 4. Implementation 5. Testing, 6. Maintenance. The results education model called "DR'E-DUMIND" is developed. It contains education and reminder for taking Iron supplementation. The software requires a small storage space (7.90 MB), installed on a smartphone with the Android platform version 4.0 .
\end{abstract}

Keywords: Educational model, Adolescent girls, Iron supplementation

\section{Introduction}

Adolescent girls are vulnerable groups of anemia, on the other hand an important group for the preparation of reproductive health. Anemia is a state of the body experiencing a decrease in the concentration of hemoglobin in adult males less than $13 \mathrm{~g} / \mathrm{dL}$ and in adult women not pregnant less than $12 \mathrm{~g} / \mathrm{dL}$.[1] According to Riskesdas data year 2012, the prevalence of anemia in adolescent girls aged 10-18 is $57.1 \%$ and at the age of 19-45 is 39.5\%.[2] The data of Riskesdas year 2013 Prevalence of adolescent anemia and women of childbearing age with 15 years old as $22.7 \%$ and in pregnant mothers 37.1\%.[3] Prevalence of expectant mother anemia aged 15-24 years old (84.6\%), 25-34 years old (33.7\%), 35-44 years old (33.6\%), and age 45-54 (24\%).[4]

Unbalanced Nutritional intake in foods consumed daily can cause anemia in adolescent girls, because if food intake is less than many iron reserves are being uncov- 
ered.[5] Anemia in adolescent girls can lead to lower learning concentration, body productivity, endurance, so it is easy to get infected.[6] If continuing to become pregnant women will contribute greatly to the pain rate of mothers and infants, miscarriage, infant birth premature, the low birth weight babies, stunting, the risk of bleeding before and during childbirth, causing death in mothers and infants. [7]

Prevention of anemia can be through a good nutritional intake and consume iron supplementation once a week which is a government program. The objectives of the government program include junior and senior high school, and women outside the school as an attempt to resolve the nutritional problem.[6] Acording to data of Riskesdas year 2018, adolescent girls who received an iron supplementation at school is $76.2 \%$ and in pregnant women as much as $26.8 \%$.[4] There is still a lack of adolescent girls knowledge about the benefits of consuming nutritious food and iron supplementation into one factor affecting the compliance of iron supplementation consumption.[8], [9] Knowledge and adherence is a very important domain in the formation of one's behavior. Adolescent girls with good knowledge do not necessarily encourage the youth to be more adherence to the iron supplementation consumption, but teenagers who comply with the iron supplementation consumption are more likely to have good knowledge. Teenagers who do not obey the consumption of iron supplementation are caused by the forgetting and lack of knowledge about the disease that will arise and get worse, and the purpose of the treatment itself.[5], [10]

The recommendations of the WHO in 2011 for the prevention and countermeasures of anemia in adolescent girls are focused on promotional and preventive activities by increasing consumption of iron high food, iron supplementation.[3] The increasing number of smartphone users in the world is making this era called the digital era. Almost all walks of life interact socially, learn, and even work by utilizing the features available on smartphones. A smartphone is a multifunctional device and can perform many tasks according to everything that is programmed by its users. Smartphones are more advanced than traditional phones, and applications can be installed according to user needs.[11] Using a smartphone is one of the new approaches by optimizing appropriate technology for health services, one of which is by increasing one's compliance and being able to educate about illness and treatment.[12] Health legislation mentions healthcare personnel can utilize technology as a promotive and preventive effort. In the other hand, during this pandemic, educational facilities are needed to minimize gathering people or coming to health services. Smartphone -based educational media can be used as one alternative. From the description, a study aimed to produce a smartphone -based education model to educate the adolescent girls about anemia and the compliance of consuming iron supplementation.

\section{Methods}

This research uses the Research and Development (R \& D) method. Design build model using 6 step System Development Life Cycle (SDLC). 


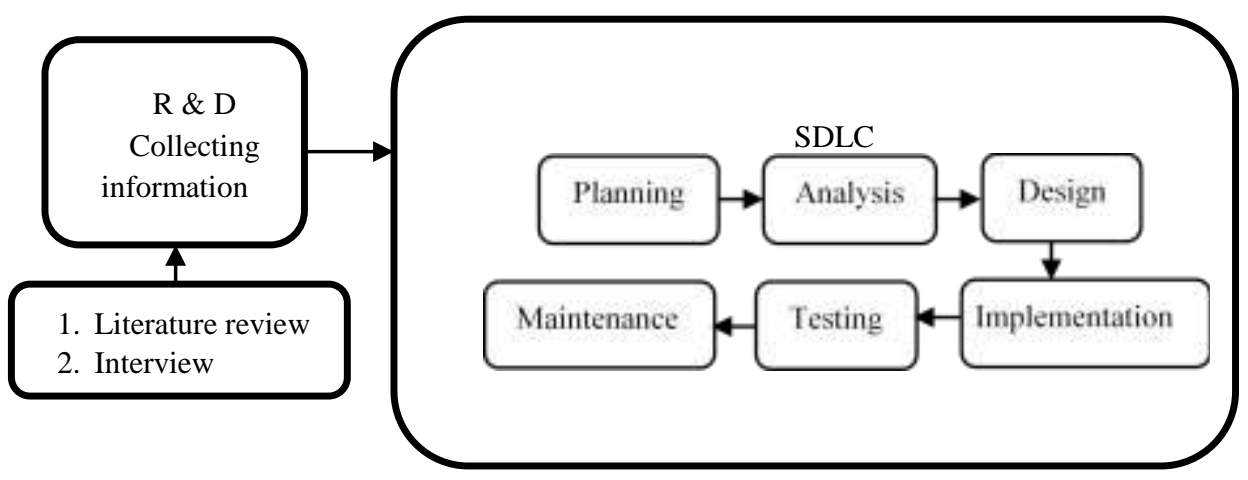

Fig. 1. Research model

The purpose of collecting information is to filter out factual information and updates related to the planning of development of educational model that will later be analyzed for problems and the needs of users and policy holders of the iron supplementation program.[13] Interviews were conducted with the Office of Health as the holder of the district level program and the Public Health Center (Puskesmas) as the Health Office's right-hand unit, who ran an iron supplementation program for adolescent girls in its area. While the literature study is done by analyzing journals, analyzing government policies, and other media to support the interview data. [14]

Design build model using 6 step System Development Life Cycle (SDLC) namely:

\subsection{Planning}

Summarizing the information with the study of the Library of government policies, journals, and from the results of the expert interviews with dietitian health care officers of Semarang District and health centers of Ungaran to see the suitability of models, educational materials with the needs of programs and media experts for the feasibility of models and content.

\subsection{Analysis}

Recognizing issues that arise to formulate concepts and determine the item of smartphone-based intervention model.

\subsection{Design}

a. Functional need is how the system reaction to the input and what the system does in the special situation. The functional needs of the following systems:

1) May display anemia information

2) Can display the iron supplementation control card

3) Can display iron supplementation

4) Can display nutrients

5) Can show alarms 


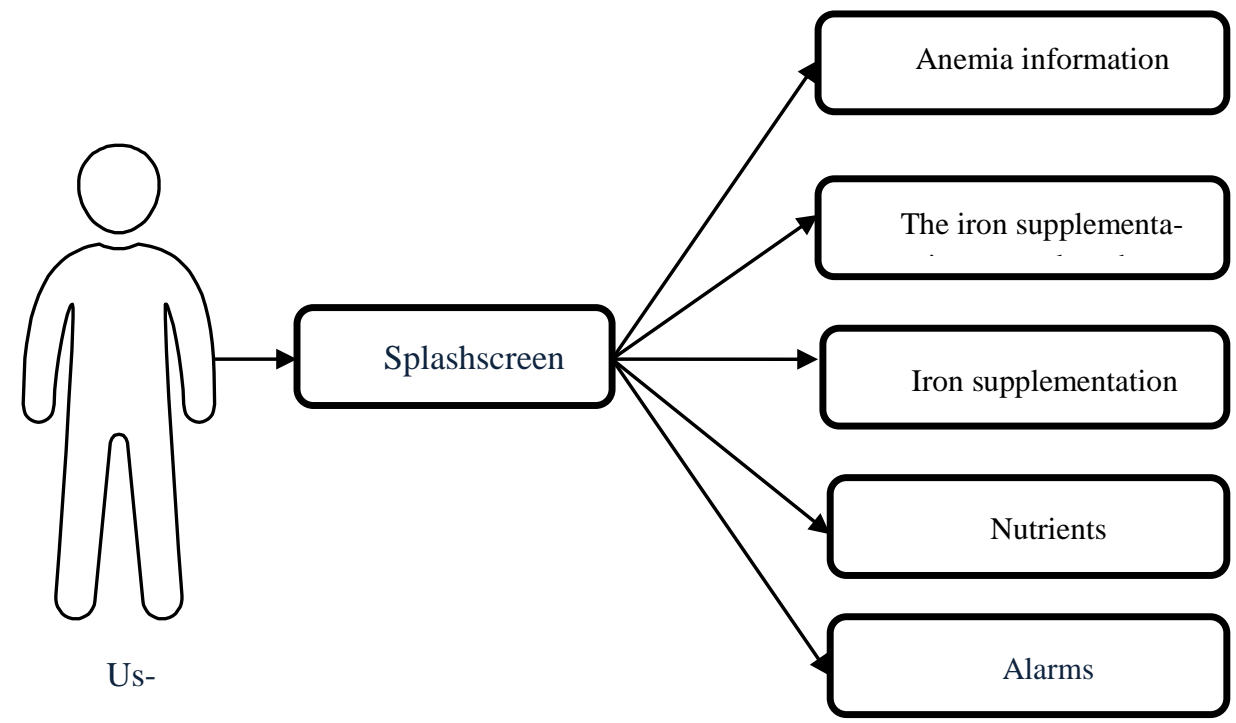

Fig. 2. Design model educational

b. Non-functional needs to support in the manufacture of educational models

1) Hardware requirement Analysis

Computers and smartphones consist of interfacing hardware and software. Software provides the instruction to the hardware to perform the tasks according to the system. Development of a smartphone-based educational model using the following hardware:

Table 1. Hardware requirements

\begin{tabular}{ll}
\hline $\boldsymbol{P c}$ /Laptop & Smartphone \\
\hline Intel Core i5-8600k Proces- & $\begin{array}{l}\text { Processor Qualcomm Snapdragon 810, } \\
\text { sor }\end{array}$ \\
\hline Quad-Core 1.6 GHz \\
\hline
\end{tabular}

2) Software Requirements Analysis

Here are the minimum specifications used to build the educational model

Table 2. Software requirements

\begin{tabular}{llll}
\hline Pc $/$ Laptop & Smartphone & & \\
\hline WINDOWS10 64bit & $\begin{array}{l}\text { Android Platform } \\
\text { (Marsmellow) }\end{array}$ & version & 6.0 \\
\hline Android Studio & Internal Storage 16GB & & \\
\hline JDK version 7 & & \\
\hline HDD 1TB & & \\
\hline
\end{tabular}


c. User needs

It is useful to determine user-needed of the users and the user specifications of the education model.

1) Users of educational models of smartphone users with Android platform version 4.0 or higher

2) Admins as Data Manager have the capability to manage databases such as changing, reducing, adding, and deleting data.

\subsection{Implementation}

System designing with the construction stage, installation, testing, and transmission of the system into the product.

\subsection{Testing}

To know the feasibility of program needs.

\subsection{Maintenance}

Including system operation, repair, evaluation, and development.

\section{Results}
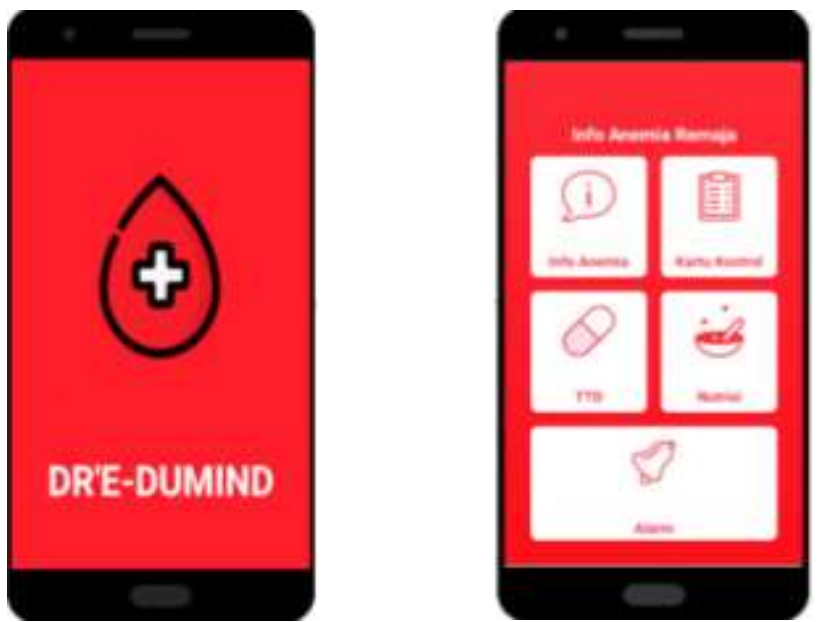

Fig. 3. The display of "DR'E-DUMIND"

Model educational android platform called "DR'E-DUMIND" contains education about anemia, iron supplementation, and alarm as a reminder to drink iron supplementation. The displayed menu contains anemia info, iron supplementation info, iron supplementation control cards, nutritional menus, and alarms. DR is an acronym for developers, E-DU is an education and information about anemia and iron supplementation, MIND is a reminder to remind the consumption of iron supplementation. Software needs a small storage space (7.90 MB), installed on a smartphone with 
Android platform version 4.0. The validation results of the material experts mentioned the anemia and iron supplementation education materials are complete, clear, easy to understand and systematic reminder according to the needs of users and programs. The application is expected to cover many goals, not only to adolescent girls. The validation of media expert said that the software was easy to install, did not require logging in, even at low smartphone specifications, was easy to use, and without the constraints of network conditions. An alarm sounds with notification that appears on the screen, so the user doesn't lose the reminder. Future research is expected to be able to implement and evaluate models in the target group and see the user's direct response through the Technology Acceptance Model (TAM) construct.

\section{Discussion}

The adolescent girls' knowledge of the dangers of anemia and the benefits of iron supplementation is still low, so compliance for the iron supplementation consumption is still lacking. This has become a government constraint to reach the iron supplementation coverage as an effort to prevent and prevent anemia in adolescent girls and women childbearing age according to $\mathrm{WHO}$ has a target to lower the prevalence of $50 \%$ anemia in 2025.[3]

The results proved that compliance to consume iron supplementation affects the incidence of anemia in adolescent girls. [8] Technological developments that can be mastered in all fields, one of which is a health field can be utilized to increase the knowledge and compliance of adolescent girls to consume iron supplementation. Technology that can be utilized at this time one of them is a smartphone, which is a technology that is almost owned by all walks of life even in school children. [15] Smartphones can be utilized by providing educational intervention to the knowledge of anemia and iron supplementation and can improve compliance by automatically giving alarms that will sound according to the specified time.[12]

The educational model "DR'E-Dumind" is a model that provides educational intervention on anemia in adolescents, covering the understanding, symptoms, causes, effects on anemia, to the prevention. In addition, education about the iron supplementation includes understanding, composition, how to consume it, side effects and storage. The education Model "DR'E-DUMIND" also provides alarms to remind adolescent girls to consume iron supplementation on a schedule that is already set by the user. In theory Information Manipulation Mc Comack mentions that a person who receives information with a certain method and repeatedly then the message conveyed will be well received.[16]

DR is an acronym for developers, E-DU is educational and information, and MIND is a reminder to remind the consumption of iron supplementation. The Alarm will automatically beep and will bring up the on-screen iron supplementation consumption notification so that the user is not missed for the iron supplementation consumption if the smartphone is in silent mode. The Education model "DR'EDUMIND" can be installed on smartphones with the Android platform version 4.0 and requires only a small storage space $(7.90 \mathrm{MB})$. The validation results of the material experts and systematic reminder of the educational material according to the needs of the user and program. Validation media experts mention software is easy to 
install even on low smartphone specifications, easy to use, and unimpeded network conditions.

The research is in line with the results of the Lewis et al study, intervention utilizing mobile phones potentially encourage a person to take disease precautions, and as a tool for health workers to provide intervention in the way of disease prevention.[17] "DR'E-DUMIND" educational model has a great potential to improve healthcare services in a promotional and preventive manner for several reasons; easy to install, not depend on the internet connection, the cost is relatively low, can be accessed anywhere and anytime without coming to the health service. The educational model "DR'E-DUMIND" is one of the alternatives that can be applied to educational interventions as a promotive and preventive effort of anemia because it supports to be applied in the pandemic condition which requires social distancing and not gathering crowds.

\section{Conclusion}

The education Model "DR ' E-DUMIND" is an educational media, information, and reminder about anemia and iron supplementation which is easy, practical, and systematic. Combining technology with promotive and preventive services offline and according to program needs. Smartphone-based education is expected that the scope of the iron supplementation can be fulfilled and support the social distancing government movement.

\section{References}

[1] M. Julie T. Vieth, David R. Lane, MD, "Anemia," Emergency Medicine Clinics of North America, vol. 32, August 20142014.

[2] K. RI, "Laporan Nasional Riset Kesehatan Dasar (RISKESDAS)," Badan Penelitian dan Pengembangan Riset Daerah, Jakarta2013.

[3] K. K. R. Indonesia, Pedoman Pencegahan dan Penanggulangan Anemia pada Remaja Putri dan Wanita Usia Subur (WUS). Jakarta: Direktorat Jenderal Kesehatan Masyarakat, 2016.

[4] K. RI, "Laporan Riset Kesehatan Dasar (RISKESDAS)," Badan Penelitian dan Pengembangan Riset Daerah, Jakarta2018.

[5] W. Budiarni and H. W. Subagio, "Hubungan pengetahuan, sikap, dan motivasi dengan kepatuhan konsumsi tablet besi folat pada ibu hamil," 2012.

[6] D. P. Kirana, "Hubungan Asupan Zat Gizi dan Pola Menstruasi dengan kejadian anemia pada remaja putri di SMA N 2 Semarang," 2011.

[7] Peraturan Menteri Kesehatan Republik Indonesia Nomor 88 Tahun 2014 Tentang Standar Tablet Tambah Darah Bagi Wanita Usia Subur dan Ibu Hamil, M. k. R. Indonesia 88, 2014.

[8] Y. Yuniarti, R. Rusmilawaty, and T. Tunggal, "Hubungan antara kepatuhan minum tablet Fe dengan kejadian anemia pada remaja putri di MA Darul Imad Kecamatan Tatah Makmur Kabupaten Banjar," Jurnal Publikasi Kesehatan Masyarakat Indonesia, vol. 2, 2015

[9] Journal article: T. Ratanasiri and R. Koju, "Effect of knowledge and perception on adherence to iron and folate supplementation during pregnancy in Kathmandu, Nepal," J Med Assoc Thai, vol. 97, pp. S67-S74, 2014. 
[10] R. Riza Alfian, "Aplikasi Pillbox Reminder Meningkatkan Kepatuhan Minum Obat PasienRawat Jalan Di Apotek Appo Farma 1 Banjarbaru," 2018.

[11] J. L. Peck, M. Stanton, and G. E. Reynolds, "Smartphone preventive health care: Parental use of an immunization reminder system," Journal of Pediatric Health Care, vol. 28, pp. $35-42,2014$

[12] L. Dayer, S. Heldenbrand, P. Anderson, P. O. Gubbins, and B. C. Martin, "Smartphone medication adherence apps: potential benefits to patients and providers," Journal of the American Pharmacists Association, vol. 53, pp. 172-181, 2013.

[13] P. D. Sugiyono, Metode Penelitian Kuantitatif, Kualitatif, dan R\&D, 23 ed. Bandung: ALFABETA, 2016

[14] M. McMurtrey, "A Case Study of the Application of the Systems Development Life Cycle (SDLC) in 21st Century Health Care," Journal of Associaation for Information Systems vol. 1,2013 .

[15] D. D. Purwanto, "Aplikasi Reminder pada Android Mobile Device," Jurnal Sistem Informasi, Sekolah Tinggi Teknik Surabaya, vol. 20, 2014.

[16] L. K. B. Eldredge, C. M. Markham, R. A. Ruiter, M. E. Fernández, G. Kok, and G. S Parcel, Planning health promotion programs: an intervention mapping approach: John Wiley \& Sons, 2016.

[17] H. K. Lewis Cole, Trace, "Text messaging as a tool for behavior change in disease prevention and management," Epidemiologic reviews, vol. 32, pp. 56-69, 2010. 